\title{
A Practical Correction Method for Added Resistance in Waves
}

\author{
by $\quad$ Masaru Tsujimoto*, M ember Kazuya Shibata*, M ember \\ Mariko K uroda ${ }^{*}$, M ember Ken Takagi ${ }^{*}$, M ember
}

\begin{abstract}
Summary
In order to estimate ship speed in actual seas it is important to calculate added resistance in waves with accuracy. Added resistance in waves usually appends the effect of wave reflection to added resistance due to ship motion. The effect is understood as the correction of the diffraction force in short waves. The conventional formula for the added resistance due to wave reflection was derived for large blunt ships. For fine ships such as a container ship, the estimation of the added resistance in short waves has poor agreement with the experimental result.

We propose a practical correction method for added resistance in waves. From the point of accuracy the correction involves a tank test in the estimation of added resistance due to wave reflection. The test is conducted with different ship speed in short waves of a single kind of wave length. The correction method and the comparison with the experiments are presented here. Thereafter the influence on decrease of ship speed in actual seas is evaluated for a large container ship.
\end{abstract}

\section{Introduction}

Reduction of $\mathrm{CO}_{2}$ shall be our duty for the next generation. In the transport section, shipping is one of the expecting measures due to the high transport efficiency. No matter how high the transport efficiency is, it should be improved continuously by ship design and ship operation. For the purpose of evaluation of $\mathrm{CO}_{2}$ emission from ships, ship speed in operation is one of the key factors since most of $\mathrm{CO}_{2}$ emission is produced by engine operation.

In order to estimate ship speed in actual seas, it is important to estimate external forces acting on a ship. Especially added resistance in waves is one of the predominant components and it should be estimated with accuracy.

The calculation method of added resistance in waves generally appends added resistance due to wave reflection to that due to ship motion. The added resistance due to wave reflection is understood as correction for the diffraction force in short waves and a semi-empirical formula was originally proposed by $\mathrm{Fujii}$ and Takahashi ${ }^{1)}$. The formula is expressed as separation of variables; hull form, wave frequency and ship speed. The functional expression of ship speed is derived from experiments for blunt ships. Thereafter Takahashi ${ }^{2)}$ revised the formula on the practical viewpoint. Faltinsen et al. ${ }^{3)}$ derived an asymptotic formula for small wave lengths. Nakamura et al. ${ }^{4)}$ made experimental investigation in short waves and Naito et al. ${ }^{5), 6), 77}$ proposed a formula based on the ray theory and numerical simulations. Ohkusu ${ }^{8)}$ also derived a formula based on the

\footnotetext{
* National M aritime R esearch Institute, Japan

** University of Tokyo
}

Received 29th A ug. 2008
Faltinsen's approach. Ueno et al. ${ }^{9)}$ derived a formula in manoeuvring motion applying Ohkusu's method. Theoretical and experimental investigation ${ }^{10), 11), 12), 13)}$ is conducted for added resistance in short waves. Matsumoto et al. ${ }^{14)}$ proposed a correction method which takes the influence of hull form above water line into account.

However, for fine ships such as a container ship the calculated value is out of application of the formulas and is poor agreement with the experimental results. Recently $\mathrm{K}$ uroda et al. ${ }^{15)}$ has proposed a correction formula for added resistance due to wave reflection from a point of accuracy.

In this paper a practical correction method of added resistance in waves for fine ships is presented. The correction method involves a tank test in regular heading waves, therefore the method takes account of the effect of the hull form above water line. The tank test is conducted with different ship speed in short waves of a single kind of wave length. Using the method, decrease of the ship speed in representative sea conditions are calculated for a large container ship as an example. The influence of the correction is presented and discussed.

\section{C alculation M ethod}

\subsection{Added resistance in regular waves}

Added resistance in regular waves $\left(R_{A W}\right)$ is composed of added resistance due to ship motion $\left(R_{A W m}\right)$ and that due to wave reflection $\left(R_{A W r}\right)$.

$$
R_{A W}=R_{A W m}+R_{A W r}
$$

$\mathrm{R}_{\mathrm{AWm}}$ is calculated by M aruo's theorem ${ }^{16)}$ combined with the ship motion.

$R_{A W r}$ is the correction factor of the diffraction effect for the added resistance in waves in terms of accuracy. It comprises the 
bluntness coefficient $\left(B_{f}\right)^{17)}$, effect of draft and frequency $\left(\alpha_{d}\right)^{18)}$ and effect of advance speed $\left(1+\alpha_{U}\right)$. The added resistance due to wave reflection proposed by Fujii and Takahashi $^{1)}$ is expressed as a following model of separation of variables;

$$
\begin{aligned}
\mathrm{R}_{\mathrm{AWr}} & =\frac{1}{2} \rho \mathrm{g} \zeta_{\mathrm{a}}{ }^{2} \mathrm{BB}_{\mathrm{f}} \alpha_{\mathrm{d}}\left(1+\alpha_{\mathrm{U}}\right) \\
\mathrm{B}_{\mathrm{f}} & =\frac{1}{\mathrm{~B}}\left\{\int_{\mathrm{l}} \sin ^{2}\left(\alpha+\beta_{\mathrm{W}}\right) \sin \beta_{\mathrm{w}} \mathrm{dl}+\int_{\mathrm{U}} \sin ^{2}\left(\alpha-\beta_{\mathrm{W}}\right) \sin \beta_{\mathrm{w}} \mathrm{dl}\right\} \\
\alpha_{\mathrm{d}} & =\frac{\pi^{2} \mathrm{I}_{1}^{2}(\mathrm{kd})}{\pi^{2} \mathrm{I}_{1}^{2}(\mathrm{kd})+\mathrm{K}_{1}^{2}(\mathrm{kd})} \\
1+\alpha_{\mathrm{U}} & =1+5 \sqrt{\mathrm{F}_{\mathrm{n}}}
\end{aligned}
$$

where

$\rho$; fluid density, $\mathrm{g}$; gravitational acceleration, $\alpha$; angle between ship course and regular waves (angle 0deg. is defined as the heading wave direction), $\zeta_{a}$; amplitude of regular waves, $B$; ship breadth, $B_{f}$; bluntness coefficient, which is determined from the shape of water plane and wave direction, $\mathrm{I}, \mathrm{Il}$; domains of integration shown in Fig. $1, \beta_{\mathrm{w}}$; slope of line element along the water line, $\mathrm{dl}$; line element along the water plane, $I_{1}$; modified Bessel function of the first kind of order 1 , $\mathrm{K}_{1}$; modified Bessel function of the second kind of order $1, \mathrm{k}$; wave number of regular waves, $d$; ship draft, $F_{n}$; Froude number.

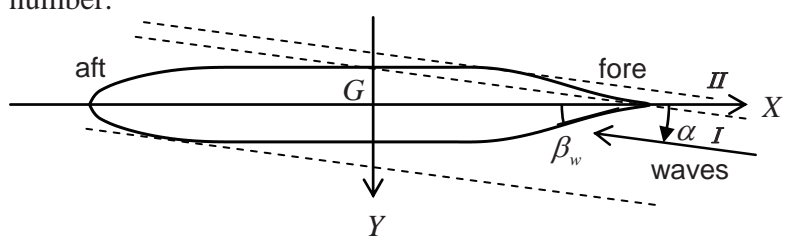

Fig.1 Coordinate system for wave reflection.

\section{Practical correction for added resistance in regular} waves

Focusing on the added resistance in short waves, it is especially important for a large ship in relation to wave spectrum. Thus correction for the estimation method for added resistance in short waves should be carried out.

In short waves the ship motion is quite small so that added resistance due to wave reflection is a predominant factor. At first experimental investigation is conducted in short waves.

Experiments are conducted at M itaka No.2 Ship Model Basin (length; 400m, width; 18m, depth; $8 \mathrm{~m}$ ) for model ships of around $6 \mathrm{~m}$ length and Ocean Engineering Basin (length; 40m, width; $27 \mathrm{~m}$, depth; $2 \mathrm{~m}$ ) for model ships of $3 \mathrm{~m}$ length.

\section{Correction for added resistance due to weve reflection}

1) Effect of draft and frequency

From experiments of wall-sided models of a fine and a blunt ship the following formula is proposed by $\mathrm{K}$ uroda et al. ${ }^{15)}$. Here $k_{e} d$ in exchange for $k d$ is used for non-dimensional frequency.

$$
\begin{aligned}
\alpha_{d}= & \frac{\pi^{2} I_{1}^{2}\left(k_{e} d\right)}{\pi^{2} I_{1}^{2}\left(k_{e} d\right)+k_{1}^{2}\left(k_{e} d\right)} \\
k_{e} & =k(1+\Omega \cos \alpha)^{2} \\
\Omega & =\frac{\omega U}{g}
\end{aligned}
$$

where

$\omega$; circular frequency of incident regular waves, $U$; ship speed.

\section{2) Effect of advance speed}

Effect of advance speed is derived from the tank test in short waves as follows;

$$
1+\alpha_{U}=\frac{\mathrm{R}_{\mathrm{AW}}-\mathrm{R}_{\mathrm{AWm}}}{\frac{1}{2} \rho \mathrm{g} \zeta_{\mathrm{a}}{ }^{2} \mathrm{BB} \mathrm{B}_{\mathrm{f}} \alpha_{\mathrm{d}}}
$$

where

$\mathrm{R}_{\mathrm{AW}}$; measured added resistance in regular waves, $\mathrm{R}_{\mathrm{AWm}}$; calculated added resistance due to ship motion, $\zeta_{a}$; measured amplitude of regular waves, $\alpha_{d}$; effect of draft and frequency calculated by Eq. (6).

The tank test should be carried out in short waves since $R_{A W r}$ mainly works in short waves. Therefore the length of short waves should be $0.5 L_{p p}$ or less; where $L_{p p}$ is ship length between perpendiculars.

From experimental investigation effect of advance speed $\left(1+\alpha_{U}\right)$ is assumed to be a power function of Froude number as follows;

$$
1+\alpha_{U}=1+\mathrm{C}_{U} \mathrm{~F}_{\mathrm{n}}^{\mathrm{m}}
$$

The coefficients of advance speed $\left(C_{U}\right)$ are presented from Fig. 2 to Fig. 6 for a container ship ( $L_{p p}=300 \mathrm{~m}$ ), a pure car carrier $\left(\mathrm{L}_{\mathrm{pp}}=190 \mathrm{~m}\right)$ and a bulk carrier $\left(\mathrm{L}_{\mathrm{pp}}=217 \mathrm{~m}\right)$; in heading $(\alpha=$ Odeg.) and oblique waves ( $\alpha=40 \mathrm{deg}$.), respectively.

From these figures it is represented that the coefficient of advance speed is approximately proportion to a linear function of Froude number.

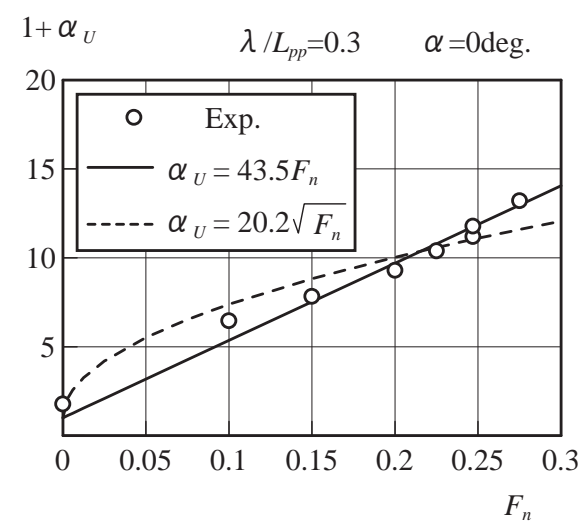

Fig.2 Effect of advance speed of added resistance due to wave reflection (a container ship in heading waves; $B_{f}=0.0585$,). 


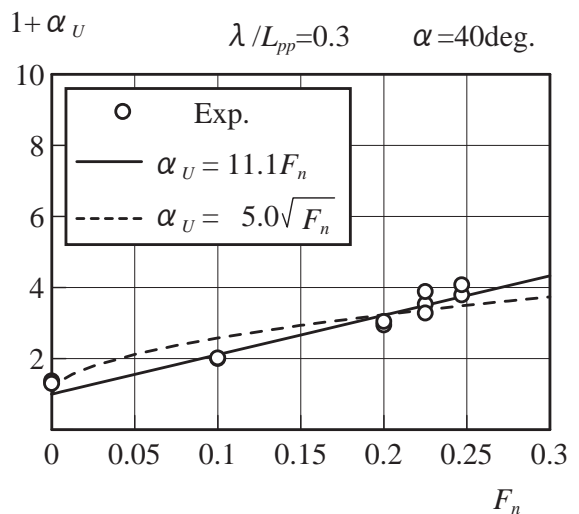

Fig.3 Effect of advance speed of added resistance due to wave reflection (a container ship in oblique waves; $B_{f}=0.267$ ).

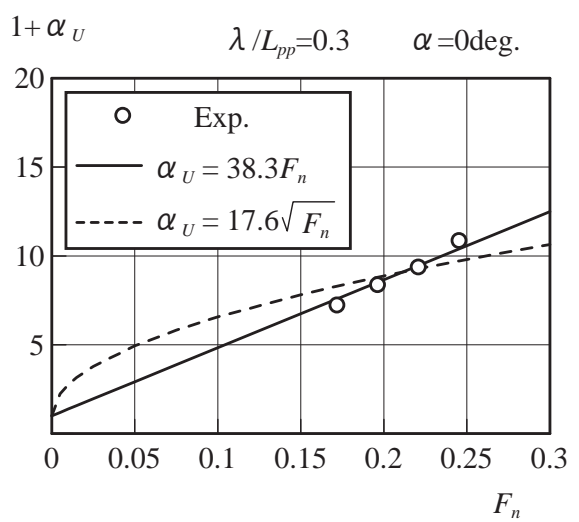

Fig.4 Effect of advance speed of added resistance due to wave reflection (a pure car carrier in heading waves; $B_{f}=0.0777$ ).

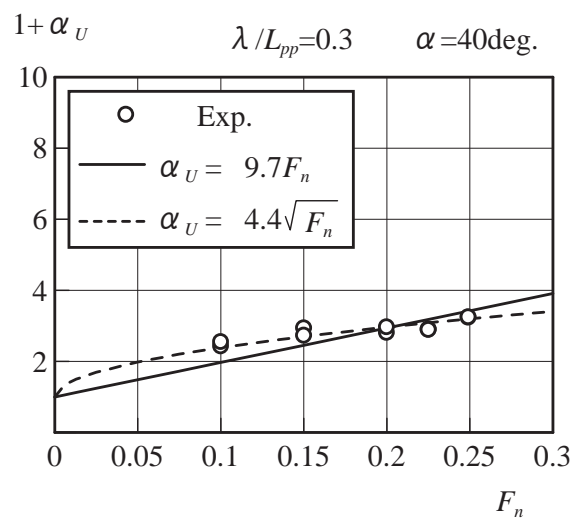

Fig.5 Effect of advance speed of added resistance due to wave reflection (a pure car carrier in oblique waves; $B_{f}=0.302$ ).

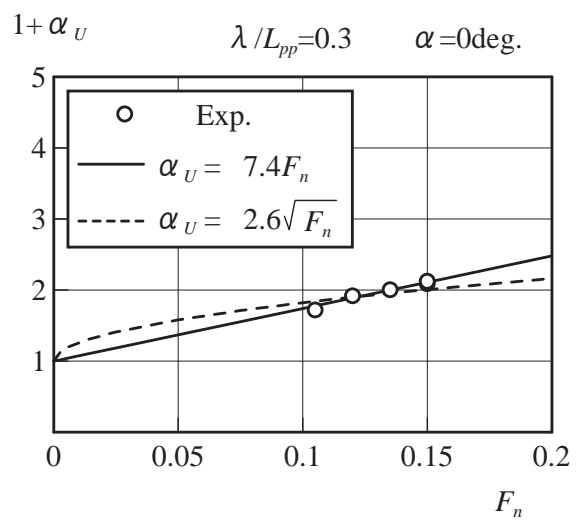

Fig.6 Effect of advance speed of added resistance due to wave reflection (a bulk carrier in heading waves; $B_{f}=0.394$ ).
Therefore the power exponent is selected as $m=1$.

$$
1+\alpha_{U}=1+\mathrm{C}_{U} \mathrm{~F}_{\mathrm{n}}
$$

\subsection{Application to added resistance in oblique waves}

The coefficient of advance speed in oblique waves could also be determined by the same procedure as mentioned above. The experiments in oblique waves are carried out for the container ship and the pure car carrier. From the experiments the obtained relation between the coefficient of advance speed and the bluntness coefficient is shown in Fig.7. A solid line in Fig.7 is derived from conventional hull forms. For reference, curves by the formulas of Fujii and Takahashi ${ }^{1)}$, Faltinsen et al. ${ }^{4}$, and $\mathrm{N}$ aito and $\mathrm{Ueda}^{7)}$ are represented in Fig.7 with these application limits as well.
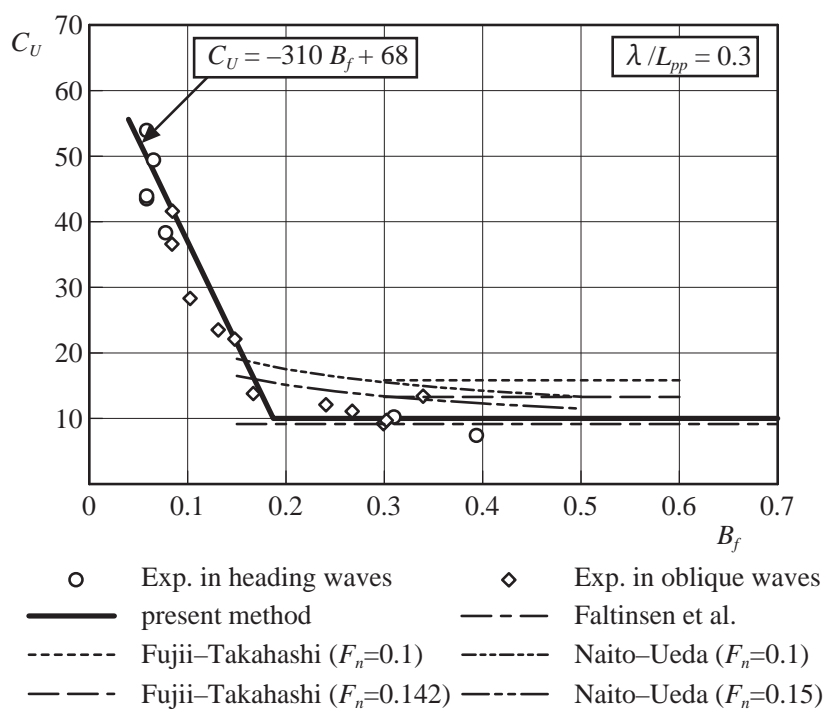

Fig.7 A practical chart for coefficient of advance speed on added resistance due to wave reflection for conventional hull form.

From the figure the following formula is proposed for practical use. The coefficient of advance speed derived from the tank test contains the effect of hull form above water line though the line in Fig.7 is derived from conventional hull forms. The following formula takes the effect into account since it involves the result of the tank test with different ship speed in short waves of a single kind of wave length.

$$
\mathrm{C}_{U}(\alpha)=\mathrm{Max}\left[\mathrm{F}_{\mathrm{C}}, \mathrm{F}_{\mathrm{S}}\right] \text { for } \mathrm{B}_{\mathrm{f}}>0
$$

i) in case; $B_{f}(\alpha=0) \geq B_{f c}$ and $B_{f}(\alpha=0) \geq B_{f s}$

$$
\begin{aligned}
& \mathrm{F}_{\mathrm{C}}=\mathrm{C}_{U}{ }^{\text {EXP }}(\alpha=0) \\
& \mathrm{F}_{\mathrm{S}}=-310 \mathrm{~B}_{\mathrm{f}}(\alpha)+68
\end{aligned}
$$

ii) in case; $B_{f}(\alpha=0)<B_{f c}$ or $B_{f}(\alpha=0)<B_{\text {fs }}$

$$
\begin{aligned}
& F_{C}=\operatorname{Min}\left[10, C_{U}{ }^{\operatorname{EXP}}(\alpha=0)\right] \\
& F_{S}=-310 B_{f}(\alpha)+310 B_{f}(\alpha=0)+C_{U}{ }^{\operatorname{EXP}}(\alpha=0)
\end{aligned}
$$

where

$\mathrm{B}_{\mathrm{fc}}=\frac{58}{310} \approx 0.187, \mathrm{~B}_{\mathrm{fs}}=\frac{68-\mathrm{C}_{\mathrm{U}}^{\text {EXP }}(\alpha=0)}{310}, \mathrm{~F}_{\mathrm{C}} ;$ a functional 
Table 1 Principal dimensions of a container ship.

\begin{tabular}{|l|c|c|}
\hline Item & \multicolumn{2}{|c|}{ Dimension } \\
\hline Length between perpendiculars $\left(\mathrm{L}_{\mathrm{pp}}\right)$ & 300.0 & $\mathrm{~m}$ \\
\hline Breadth ( $\mathrm{B})$ & 40.0 & $\mathrm{~m}$ \\
\hline Draft $(\mathrm{d})$ & 14.0 & $\mathrm{~m}$ \\
\hline Propeller diameter $\left(\mathrm{D}_{\mathrm{P}}\right)$ & 9.0 & $\mathrm{~m}$ \\
\hline Rudder area ( $\left.\mathrm{A}_{\mathrm{R}}\right)$ & 93.3 & $\mathrm{~m}^{2}$ \\
\hline A spect ratio of rudder $\left(\Lambda_{\mathrm{R}}\right)$ & 1.47 & - \\
\hline $\begin{array}{l}\text { Front projected area above water line } \\
\left(A_{\mathrm{T}} \text { ) }\right.\end{array}$ & $1,546.7$ & $\mathrm{~m}^{2}$ \\
\hline $\begin{array}{l}\text { Lateral projected area above water } \\
\text { line ( } A_{\mathrm{L}} \text { ) }\end{array}$ & $9,018.7$ & $\mathrm{~m}^{2}$ \\
\hline M aximum continuous rating ( MCR ) & 59,800 & $\mathrm{~kW}$ \\
\hline Normal rating ( NOR ) & 50,607 & $\mathrm{~kW}$ \\
\hline Engine revolution at NOR & 93.9 & $\mathrm{rpm}$ \\
\hline sea margin & 20 & $\%$ \\
\hline
\end{tabular}

symbol of the constant part, $F_{S}$; a functional symbol of the slope part, $\mathrm{C}_{\mathrm{U}}{ }^{\mathrm{EXP}}(\alpha=0)$; the coefficient of advance speed determined

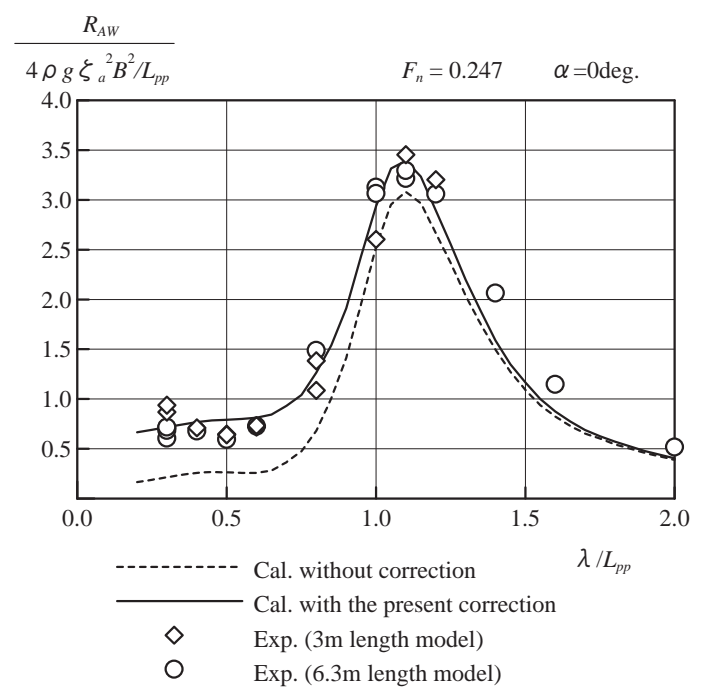

Fig.8 A dded resistance in regular waves ( $F_{n}=0.247, \alpha=0$ deg.).

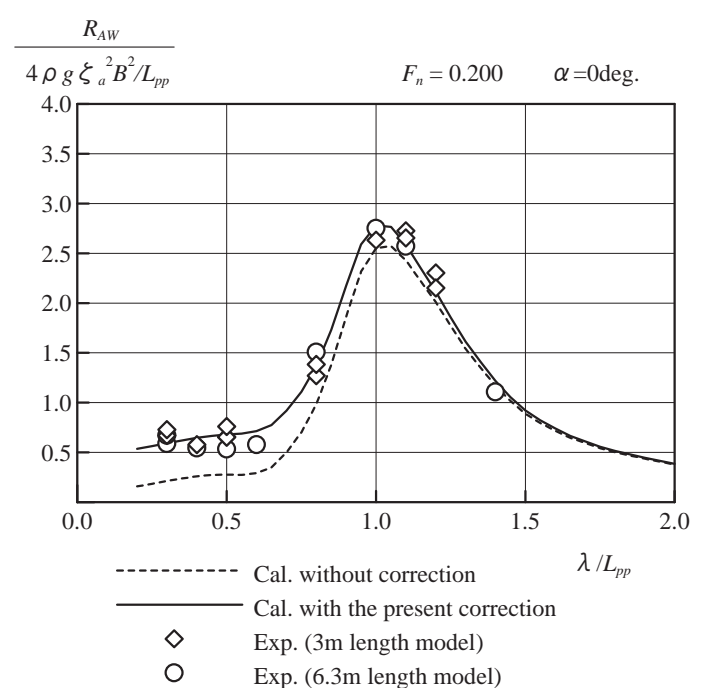

Fig.9 A dded resistance in regular waves ( $F_{n}=0.200, \alpha=0$ deg. $)$. by the tank test, $B_{f}(\alpha=0)$; the bluntness coefficient in heading waves, $B_{f}(\alpha)$; the bluntness coefficient in oblique waves.

For a container ship, of which principal dimensions are shown in Table 1 the added resistance in regular waves is calculated and presented with various wave directions and ship speed from Fig. 8 to Fig.11. Here the dotted line is calculated by the Takahashi's formula $a^{2)}$ and the solid line is calculated by the present correction method. From these figures calculation with the present correction gives good agreement in various wave directions as well as different ship speed.

\subsection{Added resistance in short crested irregular waves}

Added resistance in short crested irregular waves $\left(\tilde{R}_{A W}\right)$ is calculated by linear superposition of added resistance in regular waves. $\mathrm{E}(\omega, \alpha)$ is the directional spectrum and that prescribed in IACS Rec. No.34 ${ }^{19)}$ is used.

$$
\tilde{\mathrm{R}}_{\mathrm{AW}}=2 \iint \frac{\mathrm{R}_{\mathrm{AW}}(\omega, \alpha)}{\zeta_{\mathrm{a}}^{2}} \mathrm{E}(\omega, \alpha) \mathrm{d} \omega \mathrm{d} \alpha
$$

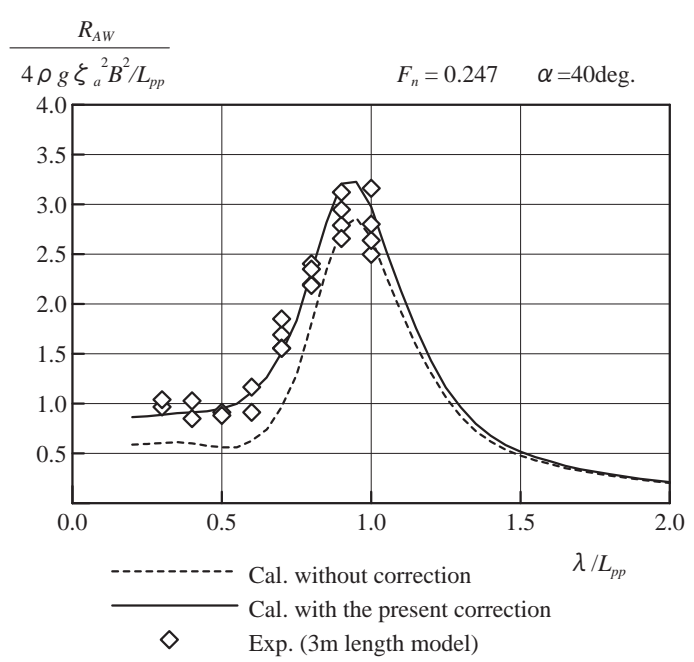

Fig.10 Added resistance in regular waves $\left(F_{n}=0.247\right.$, $\alpha=40$ deg.).

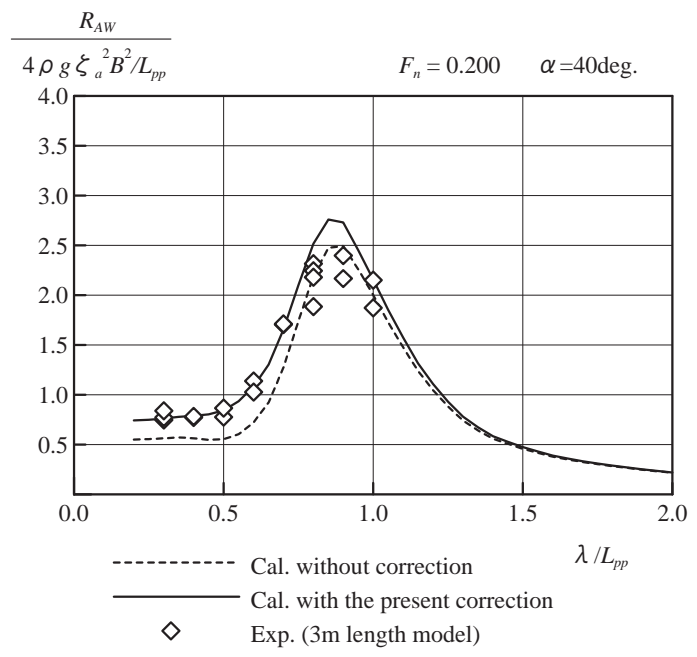

Fig.11 Added resistance in regular waves $\left(F_{n}=0.200\right.$, $\alpha=40$ deg.). 

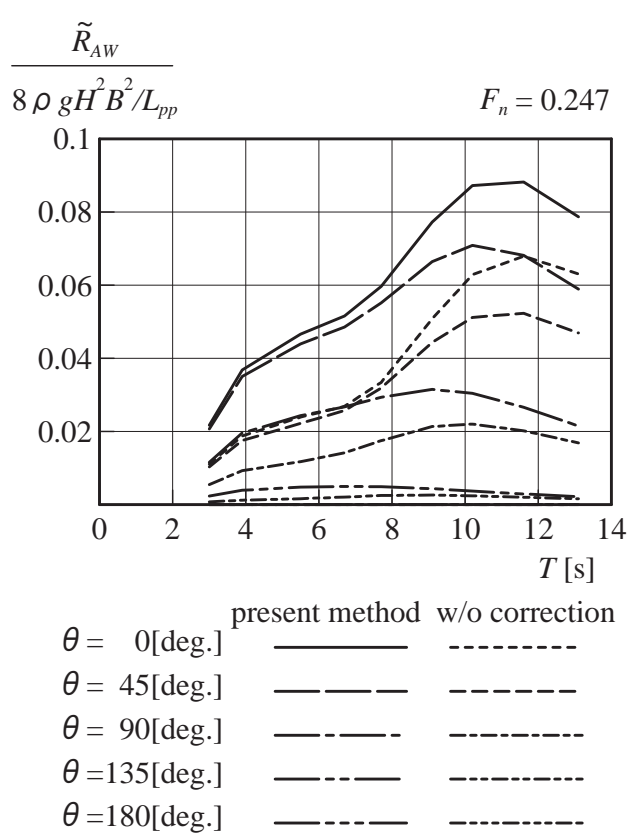

Fig.12 A dded resistance in short crested irregular waves.

A dded resistance in short crested irregular waves calculated by the present correction is shown in Fig. 12; where $\mathrm{H}$ is significant wave height, $\mathrm{T}$ is mean wave period and $\theta$ is primary wave direction (angle 0deg. is defined as the heading direction). Here the added resistance in regular following or quartering waves is fixed as zero since the value is regarded as a small one and the physical phenomena is still complicated ones.

From Fig.12 it is observed large difference between the calculation with the present correction and that without correction.

\section{Decrease of ship speed in actual sees}

Decrease of ship speed in actual seas is calculated at full loaded and constant engine output of normal rating ( NOR ) for the container ship.

\subsection{Sea conditions}

For a ship operation side, Beaufort scale of wind is friendly and convenient to analyze the ship performance in actual seas. Therefore sea conditions are determined based on B eaufort scale of wind ${ }^{20)}$ shown in Table 2.

The mean wind speed $\left(\mathrm{V}_{\mathrm{w}}\right)$ is a central value of the corresponding B eaufort number.

The significant wave height is a probable wave height which is prescribed in B eaufort scale.

To obtain the mean wave period from Beaufort scale, the following formula derived from a frequency spectrum for fully-developed wind waves is used ${ }^{21)}$.

$$
\mathrm{T}=3.86 \sqrt{\mathrm{H}}
$$

The direction of winds and waves are selected as the same direction.

Table $2 \mathrm{~W}$ eather conditions.

\begin{tabular}{|c|c|c|c|}
\hline $\begin{array}{c}\text { Beaufort } \\
\text { number }\end{array}$ & $\mathrm{V}_{\mathrm{w}}[\mathrm{m} / \mathrm{s}]$ & $\mathrm{H}[\mathrm{m}]$ & $\mathrm{T}[\mathrm{s}]$ \\
\hline BF3 & 4.4 & 0.6 & 3.0 \\
\hline BF4 & 6.9 & 1.0 & 3.9 \\
\hline BF5 & 9.8 & 2.0 & 5.5 \\
\hline BF6 & 12.6 & 3.0 & 6.7 \\
\hline BF7 & 15.7 & 4.0 & 7.7 \\
\hline
\end{tabular}

\subsection{Ship responses}

Ship speed in actual seas is treated in steady navigating condition on the fixed course. The coordinate system is shown in Fig.13. The equilibrium equations of the forces are set up on the basis of ship course. At the condition of constant ship speed, for example, the unknowns are propeller revolution $\left(\mathrm{N}_{\mathrm{p}}\right)$, drift angle $(\beta)$ and rudder angle $(\delta)$. The unknowns are solved numerically.

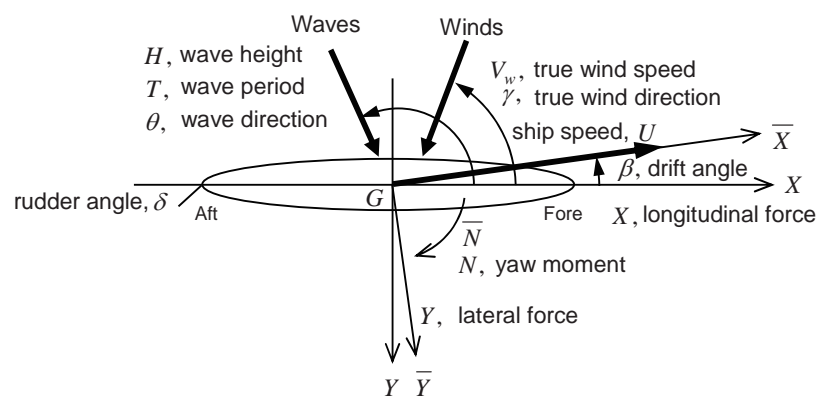

Fig.13 Coordinate system.

$$
\begin{aligned}
& \bar{X}=\mathrm{X} \cos \beta+\mathrm{Y} \sin \beta=0 \\
& \overline{\mathrm{Y}}=\mathrm{X} \sin \beta-\mathrm{Y} \cos \beta=0 \\
& \overline{\mathbf{N}}=\mathrm{N}=0
\end{aligned}
$$

where

$$
\begin{aligned}
\mathrm{X}= & \mathrm{X}_{0}(\mathrm{U})+\mathrm{X}_{\mathrm{D}}(\beta)+\mathrm{X}_{\mathrm{P}}\left(\mathrm{N}_{\mathrm{P}}, \mathrm{U}\right)+\mathrm{X}_{\mathrm{R}}(\beta, \delta) \\
& +\mathrm{X}_{\mathrm{A}}\left(\mathrm{U} ; \mathrm{V}_{\mathrm{w}}, \gamma\right)-\tilde{\mathrm{R}}_{\mathrm{AW}}(\mathrm{U}, \beta ; \mathrm{H}, \mathrm{T}, \theta) \\
\mathrm{Y}= & \mathrm{Y}_{\mathrm{D}}(\beta)+\mathrm{Y}_{\mathrm{R}}(\beta, \delta)+\mathrm{Y}_{\mathrm{A}}\left(\mathrm{U} ; \mathrm{V}_{\mathrm{w}}, \gamma\right) \\
\mathrm{N}= & \mathrm{N}_{\mathrm{D}}(\beta)+\mathrm{N}_{\mathrm{R}}(\beta, \delta)+\mathrm{N}_{\mathrm{A}}\left(\mathrm{U} ; \mathrm{V}_{\mathrm{w}}, \gamma\right)
\end{aligned}
$$

$-X_{0}$; ship resistance in still water, $X_{D}, Y_{D}, N_{D}$; hydrodynamic forces and moment due to drift motion, $X_{P}$; propeller thrust, $X_{R}, Y_{R}, N_{R}$; rudder forces and moment, $X_{A}, Y_{A}, N_{A}$; wind forces and moment, $\gamma$; mean wind direction.

The following non-dimensional expressions are applied to the forces and the moment.

$$
\mathrm{X}^{\prime}=\frac{\mathrm{X}}{0.5 \rho \mathrm{L}_{\mathrm{pp}} \mathrm{dU}}{ }^{2}, \quad \mathrm{Y}^{\prime}=\frac{\mathrm{Y}}{0.5 \rho \mathrm{L}_{\mathrm{pp}} \mathrm{dU}^{2}}, \quad \mathrm{~N}^{\prime}=\frac{\mathrm{N}}{0.5 \rho \mathrm{L}_{\mathrm{pp}}^{2} \mathrm{dU}^{2}}
$$

here $\mathrm{H}$ is in meter and $\mathrm{T}$ is in second. 
1) Resistance in still water

Resistance in still water is calculated by the following equation based on the tank test.

$$
\mathrm{X}_{0}=-\frac{\rho}{2} \mathrm{~L}_{\mathrm{pp}} \mathrm{d}\left(\mathrm{C}_{\mathrm{t} 0}+\mathrm{C}_{\mathrm{t} 1} \mathrm{U}+\mathrm{C}_{\mathrm{t} 2} \mathrm{U}^{2}+\mathrm{C}_{\mathrm{t} 3} \mathrm{U}^{3}+\mathrm{C}_{\mathrm{t} 4} \mathrm{U}^{4}\right)
$$

where $\mathrm{C}_{\mathrm{t} 0}, \mathrm{C}_{\mathrm{t} 1}, \mathrm{C}_{\mathrm{t} 2}, \mathrm{C}_{\mathrm{t} 3}, \mathrm{C}_{\mathrm{t} 4}$ are polynomial coefficients in relation to resistance in still water and ship speed.

2) Hydrodynamic forces and moment

Hydrodynamic forces and moment due to drift motion are calculated by the following formulas. The coefficients of the formulas $\left(\mathrm{C}_{\mathrm{y} \beta}, \mathrm{C}_{\mathrm{y} \beta \beta}, \mathrm{C}_{\mathrm{n} \beta}, \mathrm{C}_{\mathrm{n} \beta \beta}\right.$ ) could be calculated by the regression formulas ${ }^{22)}$ based on the tank tests. In the longitudinal force $\left(X_{D}\right)$ induced drag for a wing of a small aspect ratio is taken into account. The availability of the formulas is confirmed by the experiment of $\mathrm{M}$ inami et al. ${ }^{23)}$.

$$
\begin{aligned}
& \mathrm{X}_{\mathrm{D}}^{\prime}=-\left\{\mathrm{X}_{0}^{\prime}(\mathrm{U})-\mathrm{X}_{0}^{\prime}(\mathrm{U} \cos \beta)\right\}-\frac{\left(\mathrm{Y}_{\mathrm{D}}^{\prime} \cos \beta\right)^{2}}{\pi \Lambda_{\mathrm{H}}} \cos \beta \\
& \mathrm{Y}_{\mathrm{D}}^{\prime}(\beta)=\mathrm{C}_{\mathrm{y} \beta} \beta+\mathrm{C}_{\mathrm{y} \beta \beta} \beta|\beta| \\
& \mathrm{N}_{\mathrm{D}}^{\prime}(\beta)=\mathrm{C}_{\mathrm{n} \beta} \beta+\mathrm{C}_{\mathrm{n} \beta \beta} \beta|\beta| \\
& \Lambda_{\mathrm{H}}=\frac{2 \mathrm{~d}}{\mathrm{~L}_{\mathrm{pp}}}
\end{aligned}
$$

\section{3) Propeller thrust}

From the propeller open test the propeller thrust is calculated as follows;

$$
\begin{aligned}
X_{P} & =\rho(1-t) N_{P}{ }^{2} D_{P}{ }^{4} K_{T}(J) \\
J & =\frac{(1-w) U}{N_{P} D_{P}}
\end{aligned}
$$

where

$1-t$; thrust deduction fraction, $D_{P}$; propeller diameter, $w$; effective wake fraction, $K_{T}$; coefficient of propeller thrust in open water.

\section{4) Rudder forces and moment}

Rudder forces and moment are calculated as follows;

$$
\begin{aligned}
& \mathrm{X}_{\mathrm{R}}{ }^{\prime}=-\left(1-\mathrm{t}_{\mathrm{R}}\right) \mathrm{C}_{\delta} \sin \alpha_{\mathrm{R}} \sin \delta \\
& \mathrm{Y}_{\mathrm{R}}^{\prime}=-\left(1+\mathrm{a}_{\mathrm{H}}\right) \mathrm{C}_{\delta} \sin \alpha_{\mathrm{R}} \cos \delta \\
& \mathrm{N}_{\mathrm{R}}^{\prime}=-\left(\mathrm{x}_{\mathrm{R}}^{\prime}+\mathrm{a}_{\mathrm{H}} \mathrm{x}_{\mathrm{H}}^{\prime}\right) \mathrm{C}_{\delta} \sin \alpha_{\mathrm{R}} \cos \delta
\end{aligned}
$$

$$
\begin{aligned}
& \mathrm{C}_{\delta}=\frac{\mathrm{A}_{\mathrm{R}}}{\mathrm{L}_{\mathrm{pp}} \mathrm{d}} \frac{6.13 \Lambda_{\mathrm{R}}}{2.25+\Lambda_{\mathrm{R}}}\left(1-\mathrm{W}_{\mathrm{R}}\right)^{2} \\
& \alpha_{\mathrm{R}}=\delta-\gamma_{\mathrm{E}} \beta
\end{aligned}
$$

where

$A_{R}$; rudder area, $\Lambda_{R}$; aspect ratio of rudder, $x_{R}{ }^{\prime}=x_{R} / L_{p p}$; non-dimensional distance between the center of gravity of the hull and the rudder post: a positive value means the rudder locates in front of the center of gravity of the hull.

The interaction coefficients, $\left(1-t_{R}\right),\left(1-w_{R}\right), \gamma_{E}, a_{H}$, $\mathrm{X}_{\mathrm{H}}{ }^{\prime}$, are estimated by the regression formulas based on the tank tests $^{24), 25)}$.

5) Wind resistance

Wind resistance is calculated by the formula of Fujiwara et al. ${ }^{26)}$, which is based on model tests in a wind tunnel.

$$
\begin{aligned}
& \mathrm{X}_{\mathrm{A}}=\frac{\rho_{\mathrm{a}}}{2} \mathrm{~A}_{\mathrm{r}} \mathrm{V}_{\mathrm{r}}^{2} \mathrm{C}_{\mathrm{x}}\left(\gamma_{\mathrm{r}}\right) \\
& \mathrm{Y}_{\mathrm{A}}=\frac{\rho_{\mathrm{a}}}{2} \mathrm{~A}_{\mathrm{L}} \mathrm{V}_{\mathrm{r}}^{2} \mathrm{C}_{\mathrm{y}}\left(\gamma_{\mathrm{r}}\right) \\
& \mathrm{N}_{\mathrm{A}}=\frac{\rho_{\mathrm{a}}}{2} \mathrm{~A}_{\mathrm{L}} \mathrm{L}_{\mathrm{OA}} \mathrm{V}_{\mathrm{r}}^{2} \mathrm{C}_{\mathrm{n}}\left(\gamma_{\mathrm{r}}\right)-\mathrm{X}_{\mathrm{G}} \mathrm{Y}_{\mathrm{A}}
\end{aligned}
$$

where

$\rho_{\mathrm{a}}$; air density, $\mathrm{A}_{\mathrm{T}}$; front projected area above water line, $A_{L}$; lateral projected area above water line, $V_{r}$; relative wind speed, $\gamma_{r}$; relative wind direction, $\mathrm{L}_{\mathrm{OA}}$; length overall, $\mathrm{x}_{\mathrm{G}}$; distance between the midship and the center of gravity of the hull: a positive value means the center of gravity locates in front of the midship, $C_{x}, C_{y}, C_{n}$; coefficients of wind forces and moment.

\section{6) A dded resistance in short crested irregular waves}

A dded resistance in short crested irregular waves is calculated by the present correction.

The influence of drift motion on added resistance in waves is treated as the function of speed change.

$$
\tilde{\mathrm{R}}_{\mathrm{AW}}(\mathrm{U}, \beta)=\tilde{\mathrm{R}}_{\mathrm{AW}}(\mathrm{U} \cos \beta)
$$

7) $M$ ain engine output

M ain engine output ( BHP ) is calculated as follows;

$$
\begin{aligned}
& \mathrm{BHP}=\frac{2 \pi \mathrm{N}_{\mathrm{P}} \mathrm{Q}_{\mathrm{P}}}{\eta_{\mathrm{t}}} \\
& \mathrm{Q}_{\mathrm{P}}=\frac{\rho \mathrm{N}_{\mathrm{P}}^{2} \mathrm{D}_{\mathrm{P}}^{5}}{\eta_{\mathrm{R}}} \mathrm{K}_{\mathrm{Q}}(\mathrm{J})
\end{aligned}
$$

where

$\eta_{\mathrm{t}}$; transmission efficiency, $\eta_{\mathrm{R}}$; relative rotative efficiency, $\mathrm{K}_{\mathrm{Q}}$; coefficient of propeller torque in open water. 


\subsection{Decrease of ship speed}

Ship speed in the weather conditions prescribed in Table 2 is calculated under the constant engine power at normal rating ( NOR ). The specification of the main engine is shown in Table 1. The estimated output of the main engine is shown in Fig. 14.

The calculated ship speed is shown in Fig.15 with lines of the present correction and that without correction. In BF6 of heading winds and waves ship speed decreases $1.3 \mathrm{knot}$ from the calm condition. Comparing to the calculation with the present correction and that without correction at that weather condition, there is $0.3 \mathrm{knot}$ difference.

In following and quartering winds and waves increase of the ship speed is observed. The reason for the increase of ship speed is the decrease of wind resistance from that in a calm condition.

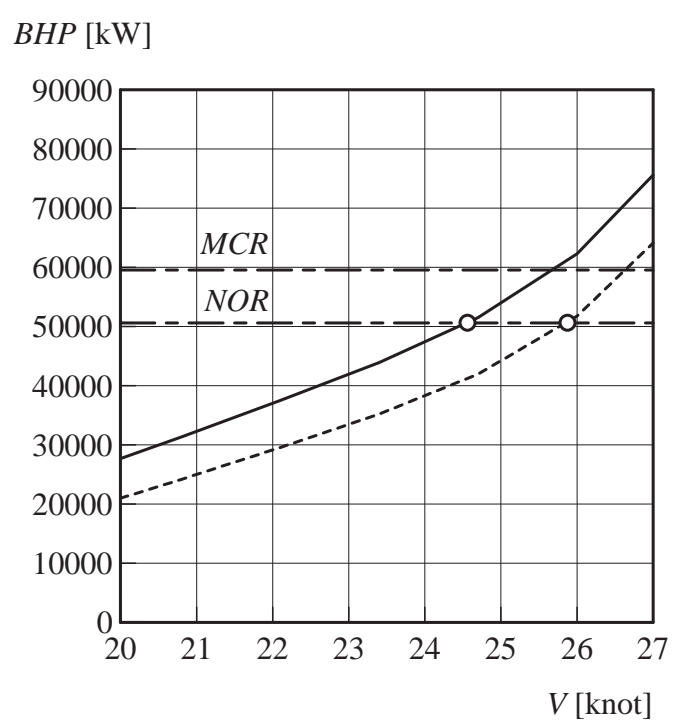

— in BF6; heading weather condition -.---- in a calm weather condition

Fig.14 Relation between main engine output and ship speed.
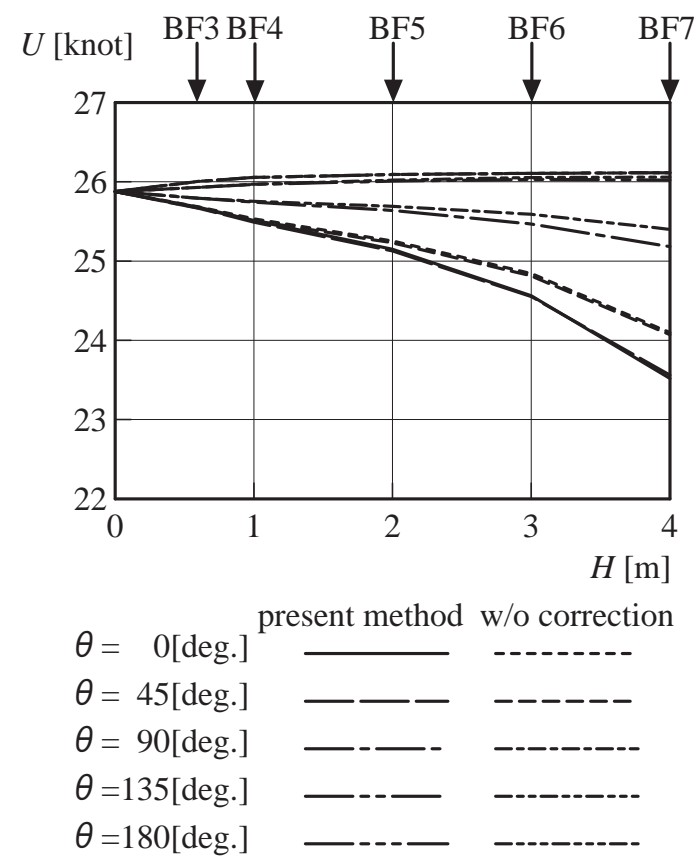

Fig.15 Ship speed in designated weather conditions.

\section{C onclusions}

In order to estimate ship speed in actual seas with accuracy a practical correction method for added resistance in waves is presented here.

The present method corrects the terms on added resistance due to wave reflection; effect of draft and frequency, and effect of advance speed as well as the application to oblique waves. The correction method involves a tank test in short waves. Therefore the calculation takes the effect of a hull form above water line into account.

Decrease of ship speed was calculated for a container ship of $300 \mathrm{~m}$ length. The ship speed without the present correction is estimated $0.3 \mathrm{knot}$ smaller than that with the present correction in BF6 of heading winds and waves. From a point of evaluation of $\mathrm{CO}_{2}$ emission, it became clear that added resistance in waves should be accurately estimated.

\section{Acknowledgements}

A part of this research was conducted as the contracted research for the ship performance index by Japan Ship Technology Research A ssociation and Class NK.

The authors thank to Dr. S. Ohmatsu for his inspiring advice, Mr. H. Sawada, Mr. T. Nimura, Mr. Y. Tsukada, and Mr. R. Fukasawa for their effort to the experiments, and all the person concerned.

\section{References}

1) H. Fujii and T. Takahashi: Experimental Study on the Resistance Increase of a Ship in Regular Oblique Waves, Proc. of 14th ITTC, Vol.4, 1975, pp.351-360.

2) T. Takahashi: A Practical Prediction Method of Added Resistance of a Ship in Waves and the Direction of its A pplication to Hull Form Design (in Japanese), Transactions of the W est-J apan Society of N aval A rchitects, N o. 75, 1988, pp.75-95.

3) O. M . Faltinsen, K. J. M insaas, N. Liapis and S. O. Skjørdal: Prediction of Resistance and Propulsion of a Ship in a Seaway, Proc. of 13th Symp. on Naval Hydrodynamics, 1980, pp.505-529.

4) S. Nakamura, S. Naito, K. M atsumoto, K. Susukida and A. Nishiguchi: Experimental Study on Resistance Increase in Regular Head W aves of a Ship with Blunt B ow (in J apanese), J ournal of the K ansai Society of Naval A rchitects, Japan, No. 190, 1983, pp.73-81.

5) S. Naito, S. Nakamura and A. Nishiguchi: Added Resistance in Short Length Waves on Ship Forms with Blunt Bow (in 
Japanese), J ournal of the K ansai Society of $N$ aval A rchitects, Japan, N o. 197, 1984, pp.39-45.

6) S. Naito, K. Fujimoto and K. K agawa: Added Resistance in Regular Head W aves of a Ship with Blunt B ow (in Japanese), J ournal of the K ansai Society of Naval A rchitects, Japan, No. 208, 1988, pp.53-59.

7) S. Naito and T. Ueda: Relation between Bow Form and Added Resistance in Short Waves (in Japanese), J ournal of the Kansai Society of Naval A rchitects, Japan, No. 217, 1992, pp.103-113.

8) M. Ohkusu: A dded Resistance in Waves of Hull Forms with Blunt Bow, Proc. of 15th Symp. on Naval Hydrodynamics, 1984, pp.1-13.

9) M. U eno, T. Nimura, H. M iyazaki and K. Nonaka: Steady W ave Forces and M oment A cting on Ships in M anoeuvring M otion in Short W aves (in J apanese), Journal of the Society of $\mathrm{N}$ aval A rchitects of Japan, $\mathrm{V}$ ol. 188, 2000, pp.163-172.

10) T. Sakamoto and E. Baba: Minimization of Resistance of Slowly Moving Full Hull Forms in Short Waves, Proc. of 16th Symp. on Naval Hydrodynamics, 1986, pp.598-612.

11) S. Ogiwara, S. Y amashita and M. M ifune: On Resistance Increase in Waves of Short Wavelength (in Japanese), J ournal of the Kansai Society of Naval A rchitects, Japan, No. 225, 1996, pp.37-45.

12) S. Kalske: Unsteady bow wave field and added resistance of ships in short waves, 13th International W orkshop on Water W aves and Floating B odies, 1998, pp.59-62.

13) S. Y amashita, T. Ishiguro and A . I to: Influence of Hull Form Parameters on Added Resistance of a Blunt Ship in Head Waves (in Japanese), Ishikawajima-Harima Engineering Review, Vol. 45, N 0. 4, 2005, pp.147-151.

14) K. Matsumoto, S. Naito, K. Takagi, K. Hirota and K. Takagishi: BEAK-BOW to Reduce the Wave Added Resistance at Sea, Practical Design of Ships and Mobile U nits, Elsevier Science B. V., 1998, pp.527-533.

15) M. Kuroda, M. Tsujimoto, T. Fujiwara, S. O hmatsu and K. Takagi: Investigation on Components of Added Resistance in Short W aves (submitting), J ournal of the Japan Society of N aval A rchitects and O cean Engineers, V ol. 8, 2008.

16) H. Maruo: Resistance in Waves, Research on Seakeeping Qualities of Ships in Japan, The Society of Naval A rchitects of J apan, V ol.8, 1963, pp.67-102.
17) T. H. Havelock: The Pressure of $W$ ater $W$ aves upon a Fixed Obstacle, Proc. of Royal Society of London, Series A, No. 963, V ol. 175, 1940, pp. 409-420.

18) F. Ursell: THE EFFECT OF A FIXED VERTICAL BARRIER ON SURFACE WAVES IN DEEP WATER, Proc. Camb. Phil. Soc., V ol.42, 1947, pp.374-382.

19) International Association of Classification Societies: Standard Wave Data, IACS Rec. No.34 (Rec. 2000/Corr. 2001).

20) World Meteorological Organization : Manual on Codes International Codes, VOLUME I.1, Part A-Alphanumeric Codes, WM O-N O. 306 (1995 edition).

21) W. G. Price and R. E. D. Bishop: Probabilistic Theory of Ship Dynamics, Chapman and Hall, London, 1974, pp.157-163.

22) K. K ijima and $Y$. Nakiri: On the Practical Prediction M ethod for Ship Manoeuvring Characteristics (in Japanese), Transactions of the West-J apan Society of $\mathrm{N}$ aval A rchitects, 2002, pp.21-31.

23) Y. Minami, T. Nimura, M. Ueno, N. Sasaki and R. Fukasawa: A study on resistance acting on container ship in oblique motion (in Japanese), Conference Proc. of the Japan Society of $\mathrm{N}$ aval A rchitects and Ocean Engineers, $\mathrm{Vol}$. 6, 2008, pp.13-14.

24) K. Kijima and Y. Nakiri: Approximate Expression for Hydrodynamic Derivatives of Ship Manoeuvring Motion taking into account of the Effect of Stern Shape (in Japanese), Transactions of the W est-J apan Society of Naval A rchitects, N o. 98, 1999, pp.67-77.

25) K. Kijima, T. Katsuno, Y. Nakiri and Y. Furukawa: On the manoeuvring performance of a ship with the parameter of loading condition, J ournal of the Society of $\mathrm{N}$ aval A rchitects of J apan, V ol. 168, 1990, pp.141-148.

26) T. Fujiwara, M. U eno and Y . Ikeda: Cruising performance of a large passenger ship in heavy sea, Proc. of Sixteenth International Offshore and Polar Engineering Conference, Vol. III, 2006, pp.304-311.

27) British Maritime Technology: Global Wave Statistics, Unwin B rothers Limited, London, 1986.

28) I. W atanabe, H. Tomita and K. Tanizawa: Winds and Waves of the North Pacific Ocean 1974-1988, Papers of Ship Research Institute, supplement N 0.14, 1992. 